\title{
ANALISIS STRUKTUR GEN DAN PROTEIN LIPID DROPLET- ASSOCIATED PROTEIN (LDAP) YANG BERPERAN DALAM BIOGENESIS MINYAK PADA TANAMAN JARAK PAGAR (Jatropha curcas L.)
}

\author{
Fredy Z. Saudale ${ }^{1}$ \\ ${ }^{1}$ Program Studi Kimia, Fakultas Sains dan Teknik, Universitas Nusa Cendana, \\ Kupang, NTT, Indonesia \\ e-mail: fredy_saudale@staf.undana.ac.id
}

\begin{abstract}
Abstrak
Tanaman Jarak Pagar atau Jatropha curcas adalah salah satu sumber biodiesel yang menawarkan keuntungan langsung dan berkelanjutan terhadap efek rumah kaca. Ekspresi protein lipid droplet-associated protein (LDAP) berkorelasi dengan tingginya akumulasi lemak, baik di biji maupun buah. Dalam studi yang menggunakan metode penjajaran sekuen jamak ini, LDAP Jatropha menunjukkan tingkat identitas yang tinggi sebesar $82.92 \%$ dengan LDAP tanaman karet; 67,50\% dengan LDAP3 Arabidopsis; 61,21\% dengan LDAP2 buah Alpukat, dan $55,65 \%$ dengan LDAP1 buah Alpukat. Namun LDAP Jatropha menunjukkan tingkat identitas yang rendah yaitu sebesar $46,01 \%$ dan $37,04 \%$ masing-masing dengan LDAP2 dan LDAP1 Arabidopsis. Struktur gen dari LDAP Jatropha terdiri atas 3 ekson dan 2 intron. Asam amino pada posisi 20-40 menunjukkan indeks hidropobisitas yang tinggi $(=2)$ dan diprediksi berinteraksi dengan LDAP dalam memfasilitasi proses biogenesis minyak pada tanaman jarak pagar.
\end{abstract}

Kata kunci: Biodiesel, jatropha, lipid droplet, LDAP

\begin{abstract}
Jatropha curcas is a source of biodiesel that offers direct and sustainable benefits to the greenhouse effect. LDAP protein expression correlates with high lipid accumulation in both seeds and fruits. LDAP plays an important role in oil biogenesis. But its presence in the Jatropha plant has never been characterized. In this study using multiple sequence alignment analysis, JatrophaLDAP showed a percent identity of $82.92 \%$ with rubber plant $L D A P ; 67.50 \%$ with Arabidopsis $L D A P 3 ; 61.21 \%$ with LDAP2 and $55.65 \%$ with LDAP1 fromAvocados. JatrophaLDAP Jatropha shows a low percent identity which is $46.01 \%$ and $37.04 \%$ respectively with LDAP2 and LDAP1 from Arabidopsis. Gene structure of JatrophaLDAP consists of 3 exons and 2 introns. Amino acids at position 20 and 40 show a high hydropobicity index (=2). Thus, this amino acid segment may play a role in interacting with membrane phospholipid monolayer oflipid droplets in facilitating oil biogenesis.
\end{abstract}

Keywords : Biodiesel, jatropha, lipid droplet, LDAP

\section{PENDAHULUAN}

Kebutuhan yang meningkat untuk kemandirian energi dan kekhawatiran yang meningkat tentang dampak kenaikan tingkat karbon dioksida telah mendorong pencarian bahan bakar terbarukan yang dapat mengurangi konsumsi bahan bakar fosil kita saat ini (Ghosh et al., 2019; Hood, 2016; Mohanty \& Swain, 2019). Strategi penting untuk mengatasi dampak bahan bakar fosil terhadap lingkungan adalah dengan menggunakan biofuel dari sumber alam yang dapat diperbaharui (Meyer et al., 2012). Salah satu bahan bakar tersebut

*Corresponding author.

Received 14 Oktober 2019; Accepted 18 September 2020; Available online 15 Oktober 2020 (C) 2020 JST. All Rights Reserved 
adalah biodiesel yang biasanya berasal dari minyak nabati dan sumber lain seperti lemak hewani (Durrett et al., 2008; POWLSON et al., 2005). Sumber energi yang ditangkap oleh tumbuh-tumbuhan berasal dari matahari, yang akan menjadi sumber energi konstan untuk beberapa miliar tahun mendatang (Greenway \& Gibbs, 2003). Energi ini kemudian dikonversi dan disimpan dalam bentuk minyak atau trigliserida (TG) (Felber \& Golay, 1995; Saudale \& Boelan, 2018).

Tanaman Jarak Pagar atau Jatropha curcas adalah salah satu sumber biodiesel yang menawarkan keuntungan langsung dan berkelanjutan pada gas rumah kaca dari sumber biodiesel lainnya (Berchmans \& Hirata, 2008; Gübitz et al., 1999; Lu et al., 2009; Openshaw, 2000; Pramanik, 2003; Silitonga et al., 2011; Tiwari et al., 2007). Jarak pagar merupakan tumbuhan semak berkayu yang banyak ditemukan didaerah tropik. Secara global, jarak pagar telah menarik minat peneliti karena mengandung minyak yang tidak dapat dimakan, tidak menciptakan konflik makanan versus bahan bakar, dan dapat digunakan untuk menghasilkan biodiesel dengan hasil kinerja yang sama atau lebih baik saat diuji di mesin diesel (Berchmans \& Hirata, 2008; Eboibi et al., 2018; Fuentes et al., 2018; Lu et al., 2009; Tiwari et al., 2007).

Tetesan lipid (Lipid droplets) memainkan peran penting dalam siklus hidup tanaman sebagai tempat penyimpanan lipid dalam bentuk TG (Chapman et al., 2012; Goodman, 2008; Horn et al., 2013), Sekarang telah banyak diketahui bahwa tetesan lipid memiliki banyak fungsi di luar penyimpanan lipid dalam biji dan bahwa semuanya terdapat di hampir semua jenis sel tanaman, yang banyak di antaranya tidak menumpuk jumlah lipid yang cukup besar, seperti selsel di daun, batang, dan akar (Cruz et al., 2019; Olzmann \& Carvalho, 2019). Ada juga bukti yang muncul bahwa tetesan lipid adalah organel yang sangat dinamis yang terlibat dalam berbagai proses seluler dan respons fisiologis, beberapa di antaranya tampak dilestarikan di antara banyak eukariota (Martin \& Parton, 2006). Dua protein pada buah Alpukat (Persea Americana) telah diketahui terletak pada permukaan tetesan lipid (Lipid droplets) yang mempunyai kemiripan tinggi dengan persentase identitas mencapai 86\% (Horn et al., 2013). Dua protein tersebut diberi nama "lipid droplet-associated protein 1 dan 2' atau disingkat LDAP1 dan LDAP2. Dilaporkan juga bahwa ekspresi gen LDAP1 dan LDAP2 selama pengembangan mesocarp alpukat mengalami peningkatan yang berkorelasi dengan akumulasi minyak. Pada tanaman Arabidopsis thaliana juga telah diketahui mempunyai 3 isoform LDAP yaitu LDAP1, LDAP2 dan LDAP3 (Gidda et al., 2016). Analisis proteomik yang paling signifikan menunjukkan bahwa tingkat LDAP sesuai dengan tingkat akumulasi minyak. Secara keseluruhan, pengamatan ini mendukung peranan protein LDAP dalam biogenesis tetesan lipid dan akumulasi TG dalam jaringan kaya lipid pada buah alpukat (Persea Americana) dan Arabidopsis thaliana. Melihat peranan LDAP dalam pembentukan TG, maka penelitian ini berusaha untuk menemukan protein homolog dari LDAP pada tanaman Jarak Pagar Jatropha curcas, yang sampai saat ini belum pernah di teliti dan di karakterisasi. Dengan mengetahui karakteristik molekuler dari struktur gen dan protein LDAP, maka kloning dan produksi protein rekombinan LDAP akan bisa dilakukan. Protein rekombinan LDAP yang dihasilkan kemudian bisa digunakan dalam eksperimen knock down (pendeaktivan) dan overekspresi atau dalam rekayasa genetika LDAP dalam menghasilkan TG yang lebih melimpah pada tanaman Jatropha curcas.

\section{METODE}

Gen, Protein LDAP dan spesies tanaman Tanaman Jarak Pagar Jatropha Curcas (LDAP, nomor akses XP_012089011.1) Buah advokat Persea americana (LDAP1, nomor akses KF031141.1; LDAP2, nomor akses KF031142), Tanaman Aradidopsis thaliana (LDAP1, nomor akses NP_176904; LDAP2, nomor akses NP_182299; LDAP3, nomor akses NP_187201), Tanaman Karet Hevea brasiliensis (LDAP, nomor akses AG095096) 


\section{Pengunduhan urutan gen LDAP dari database Genomik}

Informasi urutan DNA dan asamasam amino Protein LDAP dari tanaman Arabidopsis thaliana dan Jarak Pagar Jatropha curcas diambil dari database genomik pada NCBI (https://www.ncbi.nlm.nih.gov/), dan KEGG (www.genome.jp/). Sekuens protein LDAP3 (Lipid Droplet-Associated Protein) yang mengandung 246 asam-asam amino dari tanaman Arabidopsis thaliana digunakan sebagai input (query) pada pencarian protein dan DNA homolog dari spesies tumbuh-tumbuhan lain termasuk Jarak pagar melalui pencarian dengan TBLASTN (https://blast.ncbi.nlm.nih.gov/) pada database genomik (McGinnis \& Madden, 2004; Ye et al., 2006).

\section{Persejajaran Sekuens Jamak, domain dan protein homolog}

Sekuen-sekuen asam amino yang lengkap yang mengkode LDAP kemudian dianalis urut-urutan asam-asam amionya dengan menggunakan Clustal Omega (https://www.ebi.ac.uk/Tools/msa/clustalo/) (Sievers et al., 2011; Sievers \& Higgins, 2018). Sekuens-sekuens yang dihasilkan yang mengkode region Rubber Elongation Factor Protein (REF) pada protein LDAP dianalisis dengan menggunakan Pfam (http://pfam.xfam.org) yang didasarkan atas pencarian dengan menggunakan model Hidden Markov untuk keseluruhan sekuen gen LDAP (Bateman et al., 2004). Analisis hidropati dilakukan dengan program ProtScale

(https://web.expasy.org/protscale/)

(Gasteiger et al., 2005)

\section{Struktur gen, intron dan ekson LDAP}

Sekuens-sekuens yang teridentifikasi dianalisis lebih lanjut kandungan intron, ekson, dan Open Reading Frame (ORF) menggunakan program Splign (https://www.ncbi.nlm.nih.gov/sutils/splign/s plign.cgi) dengan prediksi struktur gen yang didasarkan Model Hidden Markov.

\section{Konstruksi pohon filogenetik}

Urutan asam-asam amino dari protein LDAP tanaman Jarak Pagar digunakan untuk mengidentifikasi isoform-isoform LDAP dari spesies tanaman lain. Pohon filogenetik dihasilkan menggunakan BLAST Tree View pada NCBI (http://www.ncbi.nlm.nih.gov/blast/treeview/) dengan metode neighbor-joining dengan matriks jarak yang ditentukan oleh model Jones-Taylor-Thornton (Brinkman et al., 2001; Jones et al., 1992)

\section{HASIL DAN PEMBAHASAN}

Pencarian sekuen-sekuen protein yang mirip dengan LDAP dari Arabidopsis menggunakan T BLAST Protein pada NCBI menampilkan nukleotida dari Tanaman Jarak pagar (Jatropha curcas) dengan tingkat indentitas sebesar 65\% (nomor akses XM 012233621). Informasi dalam database yang muncul di NCBI nukleotida masih dalam tahap prediksi yang menyatakan kemiripan dengan gen Arabdipsis yang menyandikan LDAP yang berperan dalam biogenesis lipid (kode anotasi At3g05500) (Gidda et al., 2013, 2016). Nukelotida dari Jatropha ini diberikan kode anotasi REF/SRPP-like At3g05500 atau At3g05500 yang mempunyai domain yang bernama "Rubber Elongation Factor (REF)" dan "Small Rubber Particle Protein (SRPP)" yang berperan dalam biosintesis karet alam. Dalam paper ini nukleotida dari Jatropha tersebut disebut sebagai gen LDAP. Gen LDAP ini mempunyai 1208 pasangan basa yang mengkodekan 240 asam amino dari protein LDAP Jatropha curcas.

Penyejajaran sekuen jamak (Multiple Sequence Alignments) merupakan penyejajaran sekuen yang meliputi lebih dari dari satusekuen DNA atau protein baik dari spesies yang sama maupun yang berbeda (Chenna et al., 2003). Penyejajaran ini bertujuan untuk melihat homologi atau kemiripan urutan basa-basa purin, pirimidin maupun residu-residu asam amino dari suatu protein untuk melihat kedekatannya secara evolusi dari dari satu spesies dengan spesies yang lain. 
A

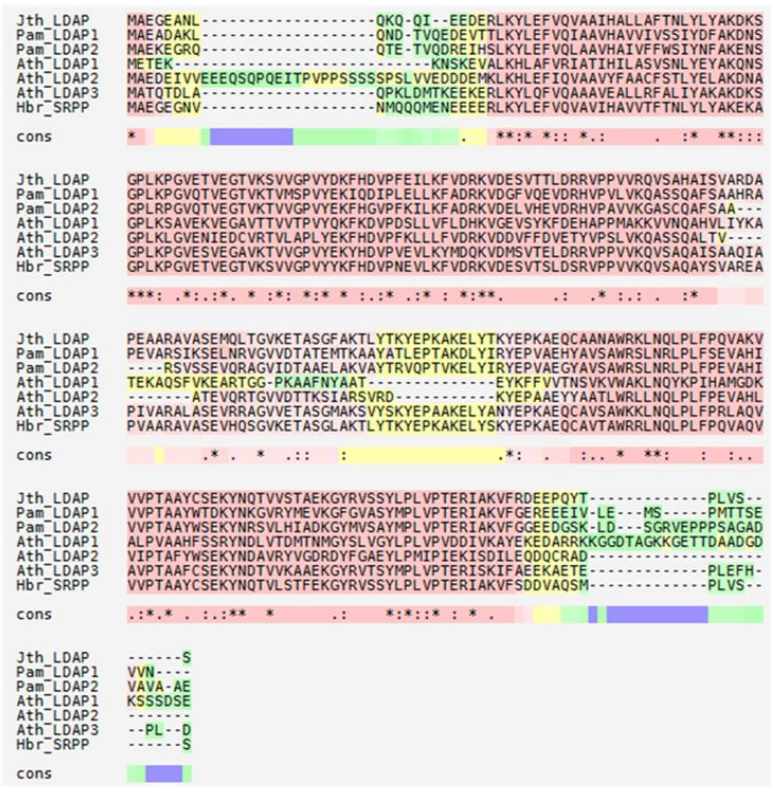

B Phylogenetic Tree

This is a Neighbour-joining tree without distance corrections.

Download Phylogenetic Tree Data

Branch length: $\bullet$ Cladogram $\bigcirc$ Rea

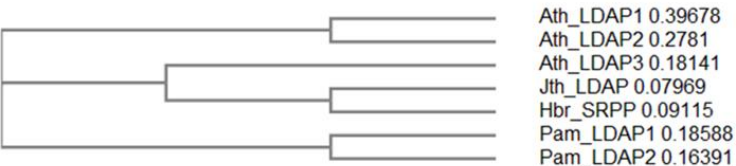

Gambar 1. Analisis Sekuens Multiple (ASM) protein LDAP dari Jarak Pagar dengan tanaman lain.

(A) Analisis dilakukan menggunakan program $\mathrm{T}$ Coffee yang tersedia di http://tcoffee.crg.cat/apps/tcoffee/do:regular Asam-asam amino yang mempunyai skor identitas yang tinggi ditera dengan kotak berwarna merah muda (skor 91-93).Kotak yang berwarna kuning menunjukkan skor identitas yang sedang, sedangkan kotak diwarnai hijau dan ungu mempunyai skor identitas yang sangat rendah, (B). Analisis pohon filogenetik (Phylogenetic Tree) (Ath_LDAP1, Arabidopsis thaliana LDAP1; Ath_LDAP2, Arabidopsis thaliana LDAP2; Ath_LDAP3, Arabidopsis thaliana LDAP3; Jth_LDAP, Jatropha curcas LDAP; $\mathrm{Hbr}$ SRPP, Hevea brasiliensisSRPP; Pam_LDAP1; Persea Americana LDAP1 dan Pam_LDAP2; Persea Americana LDAP2).

Kedekatan ini bisa berimplikasi terhadap fungsi dan peranan yang mungkin sama bahkan berbeda dari suatu protein yang sama dari sejumlah spesies yang berbeda. Penyejajaran sekuen jamak ini sangat penting sebagai kajian pendahuluan dari eksperimen molekuler dari protein yang sedang di kaji.

Seperti ditunjukkan pada Gambar 1A, penyejajaran antara sekuens protein LDAP dari tanaman Jarak pagar dengan spesies yang lain menunjukkan tingkat identitas kekerabatan dan konservasi yang tinggi pada sekuen di area pertengahan yang ditunjukkan dengan kotak berwarna merah muda. Pada Gambar 1B ditunjukkan hubungan kedekatan antara sekuen protein LDAP Jatropha dengan spesies yang lain. Terlihat pada pohon filogenetik bagaimana sekuen protein LDAP Jatropha mempunyai hubungan yang dekat dengan SRPP/LDAP dari tanaman karet Hevea dan LDAP3 dari tanaman Arabidopsis thaliana.

Hubungan kedekatan secara evolusi ini kemudian diperkuat dengan tingginya persentase dari asam-asam amino yang identik berdasarkan penyejajaran sekuen 
jamak dari Jatropha, Arabidopsis dan Hevea. Seperti ditunjukkan pada tabel 1, LDAP Jatropha menunjukkan tingkat identitas yang tinggi sebesar $82.92 \%$ dengan LDAP tanaman karet; 67,50\% dengan LDAP3 Arabidopsis; 61,21\% dengan LDAP2 buah Alpukat dan 55,65\% dengan LDAP1 buah Alpukat. Namun LDAP Jatropha menunjukkan tingkat identitas yang rendah yaitu sebesar $46,01 \%$ dan 37,04\% masing-masing dengan LDAP2 dan LDAP1 Arabidopsis.

Salah satu cara untuk mengidentifikasi gen adalah dengan cara menyejajarkan sekuen transkrip (mRNA/cDNA) dengan sekuen genomik. Seperti diketahui pada eukariota, DNA tersusun atas bagian-bagian yang dikenal dengan exon dan intron. Exon adalah daerah pada sekuen DNA genomik yang akan diterjemahkan dan dimasukkan dalam sekuens mRNA. Sementara intron adalah daerah pada sekuens DNA genomik yang tidak akan diterjemahkan atau ditranskripsi menjadi mRNA. Untuk mengetahui dengan tepat identitas gen LDAP yang akan diterjemahkan, maka analisis terhadap struktur gen LDAP dari Jatropha dilakukan dengan menggunakan struktur LDAP dari Arabidopsis sebagai referensi. Program Bioinformatika Splign dari NCBI digunakan untuk menandai bagian mana dari DNA genomic dari LDAP Jatropha yang diterjemahkan (exon) dan bagian mana yang tidak (intron).

Seperti terlihat pada Gambar 2, penyejajaran transkrip LDAP dengan DNA genomic menunjukkan bahwa LDAP Jatropha terdiri atas 3 ekson dan 2 intron. Sebagai pembanding, LDAP Arabdiposis juga mempunyai 3 ekson dan 2 intron. Analisis dengan spesies yang lain juga menunjukkan pola yang sama yaitu mempunyai 3 ekson dan 2 intron pada struktur gen yang menyandikan LDAP (Data tidak ditampilkan). Analisis ini walaupun masih bersifat tentatif tapi bermanfaat di dalam perancangan protein rekombinan LDAP yang dihasilkan melalui kloning. Informasi ini memberikan data area mana yang bisa menjadi target dari primer maju (forward primer) dan primer balik (reverse primer) dalam pelaksanaan kloning LDAP dari Jatropha.

Untuk mengetahui tingkat hidrofobisitas dari asam-asam amino pada protein LDAP maka dilakukan analisis Hidropati (D'Onofrio, Jabbari, Musto, \&Bernardi, 1999). Ini digunakan untuk mengkarakterisasi atau mengidentifikasi bentuk struktur atau domain protein. Analisis hidropati ditunjukkan dengan gambar grafik dengan urutan residu asam amino protein pada sumbu $\mathrm{x}$-nya, dan tingkat hidrofobisitas dan hidrofilisitas pada sumbu y-nya. Ada sejumlah metode untuk mengukur tingkat interaksi pelarut polar seperti air dengan asam amino spesifik. Misalnya, skala Kyte-Doolittle menunjukkan asam amino hidrofobik, sedangkan skala Hopp-Woods mengukur residu hidrofilik. Menganalisis bentuk plot hidropati memberikan informasi tentang struktur parsial protein (Damodharan \& Pattabhi, 2004).

Seperti ditunjukkan pada Gambar 3 pada LDAP Jatropha asam-asam amino pada residu 20-40 indeks hidropobisitas sebesar $=<2$ yang mengimplikasikan bahwa kemungkinan di area ini asam-asam amino yang cenderung bersifat kurang hidrofilik lebih tersembunyi dari kontak dengan bagian permukaan dan lebih berinteraksi dengan bagian dalam dari membrane lipid dua lapis pada lipid droplet. Perbandingan dengan LDAP dari buah Alpukat menunjukkan indeks spektrum yang hampir mirip dengan LDAP dari Jatropha. Namun demikian, terlihat perbedaan plot hidropati yang kontras dengan tanaman Arabidopsis thaliana. Semua isoform LDAP dari Arabidopsis mempunyai kemiripan yaitu mempunyai kecenderungan hidrofobisitas yang tinggi pada hampir semua asam-asam aminonya. 
Tabel 1. Persentase Identitas Asam Amino Penyusun Protein LDAP Berdasarkan Analisis Penjajaran Jamak.

\begin{tabular}{lccccccc}
\hline & Ath_LDAP & Ath_LDAP & Ath_LDAP & Jth_LDA & Hbr_SRP & Pam_LDAP & Pam_LDAP \\
& $\mathbf{1}$ & $\mathbf{2}$ & $\mathbf{3}$ & $\mathbf{P}$ & $\mathbf{P}$ & $\mathbf{1}$ & $\mathbf{2}$ \\
\hline Ath_LDAP1 & 100.00 & 32.51 & 34.68 & 37.04 & 36.99 & 31.86 & 32.60 \\
Ath_LDAP2 & 32.51 & 100.00 & 43.52 & 46.01 & 46.30 & 46.51 & 47.44 \\
Ath_LDAP3 & 34.68 & 43.52 & 100.00 & 67.50 & 65.02 & 54.51 & 55.27 \\
Jth_LDAP & 37.04 & 46.01 & 67.50 & 100.00 & 82.92 & 55.65 & 61.21 \\
Hbr_SRPP & 36.99 & 46.30 & 65.02 & 82.92 & 100.00 & 53.11 & 60.26 \\
Pam_LDAP & 31.86 & 46.51 & 54.51 & 55.65 & 53.11 & 100.00 & 65.02 \\
1 & & & & & & & \\
Pam_LDAP & 32.60 & 47.44 & 55.27 & 61.21 & 60.26 & 65.02 & 100.00 \\
2 & & & & & & & \\
\hline
\end{tabular}

Keterangan:Ath $=$ Arabidopsis thaliana, $\mathrm{Jth}=$ Jatropha curcas, $\mathrm{Hbr}=$ Heveabrasilensis, Pam $=$ Perseaamericana

\section{A. PREDIKSI STRUKTUR GEN LDAP Jatropha curcas}

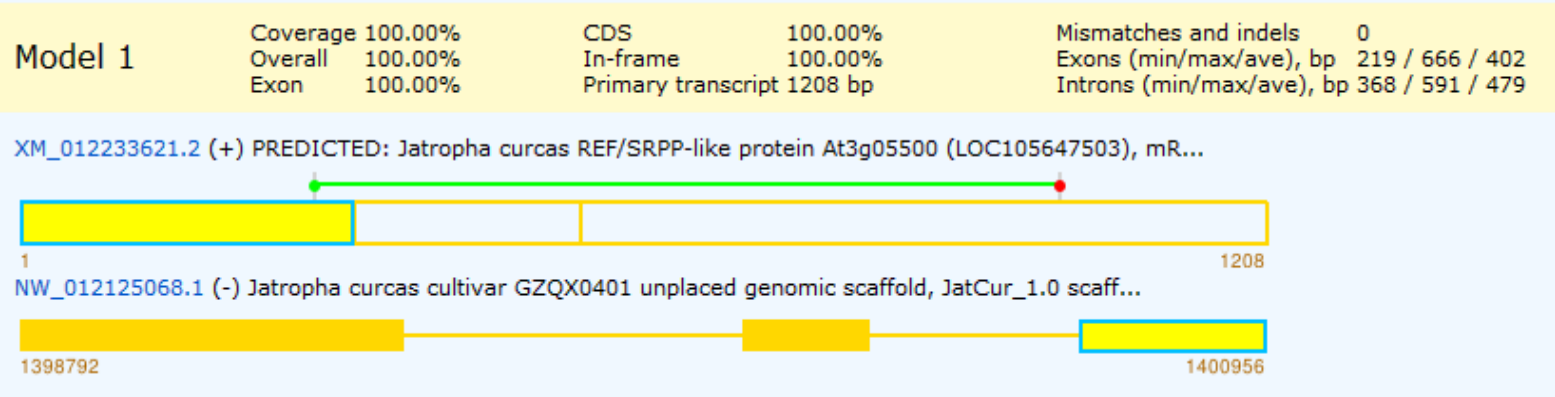

\section{B. STRUKTUR GEN LDAP3 Arabidopsis thaliana}

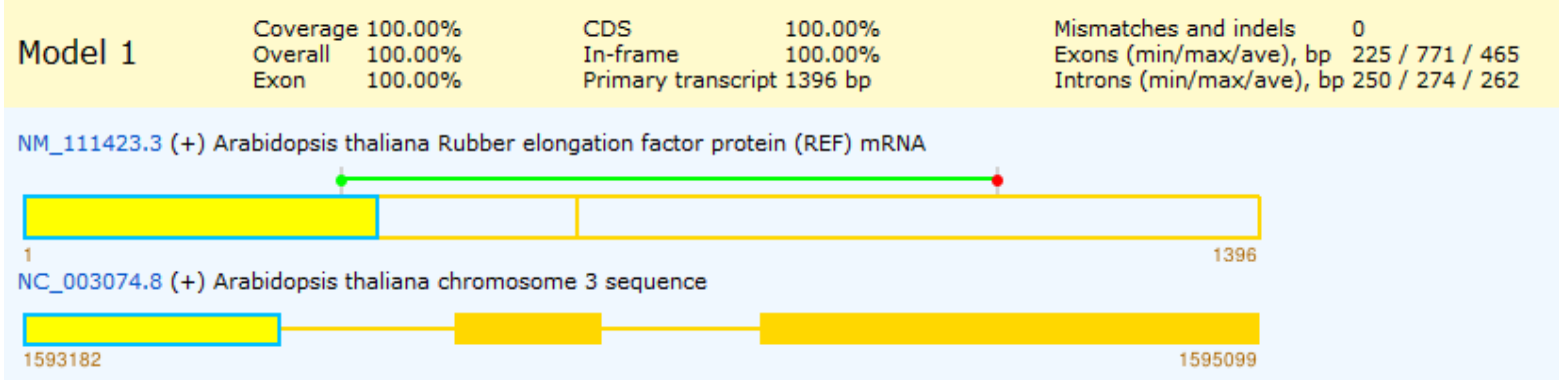

Gambar 2. Analsis struktur gen terhadap genomic dari LDAP.

(A) Prediksi struktur gen LDAP dari tanaman Jarak Pagar (XM_012233621.2) dengan struktur genomiknya. $(\bar{B})$ struktur dari gen LDAP3 dari tanaman Aradbidopsis thaliana yang telah diketahui sebagai pembanding. Analisis dilakukan dengan program Splign pada database NCBI (https://www.ncbi.nlm.nih.gov/sutils/splign/spli gn.cgi). 


\section{A. Jatropha LDAP}

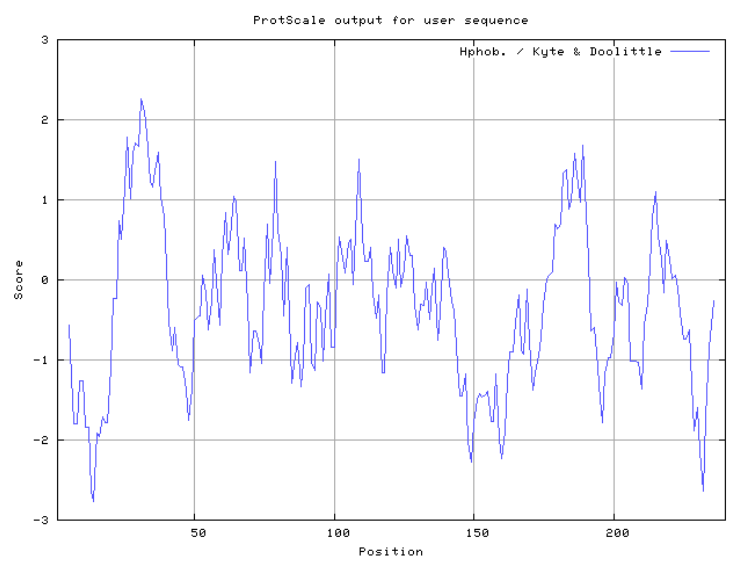

C. Persea LDAP1

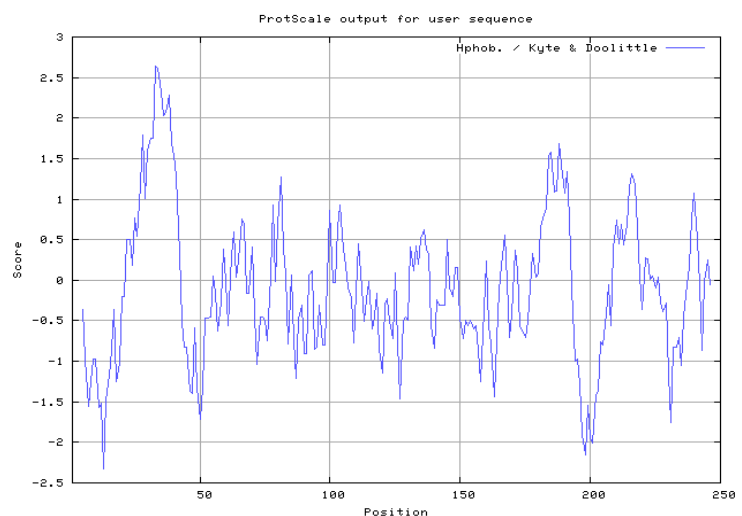

E. Persea LDAP2

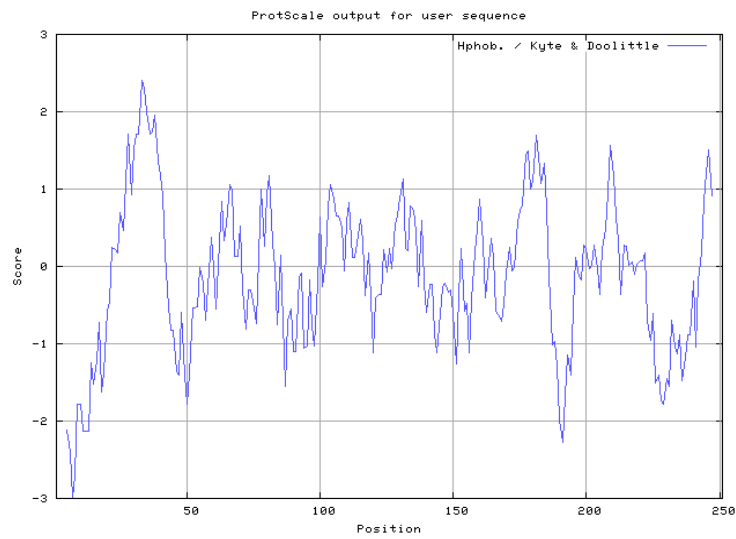

B. Arabidopsis LDAP1

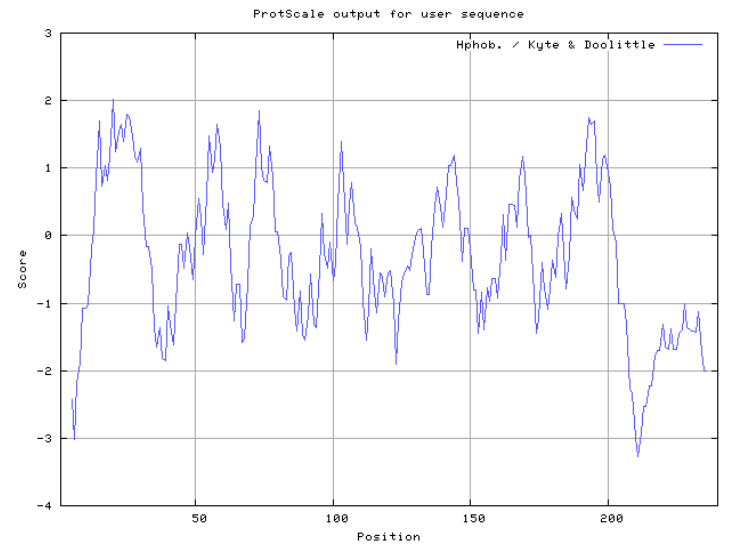

D. Arabidopsis LDAP2

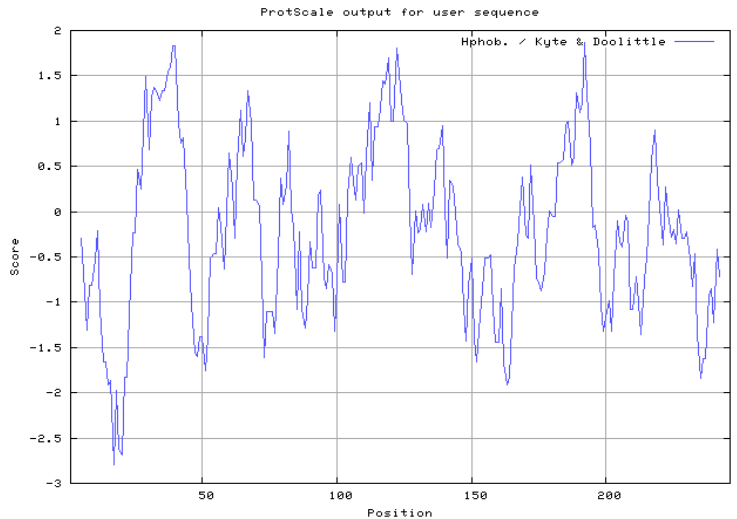

F. Arabidopsis LDAP3

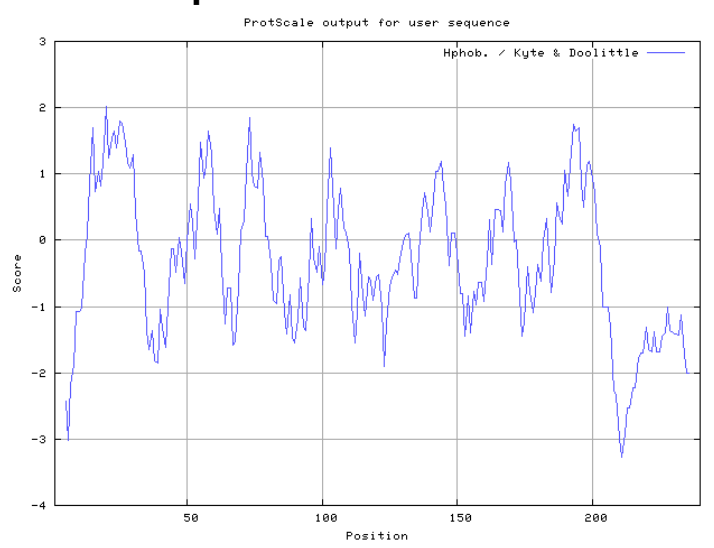

Gambar 3. Analisis Hidropati dari protein LDAP

(A) Tanaman Jarak Pagar Jatropha Curcas (B), (D), (F) Arabidopsis thaliana, dan (C), (E) tanaman Karet Persea Americana. Analisis, kurva, dan indeks hidropati didapat melalui progam ProtScale (https://web.expasy.org/protscale/).

\section{SIMPULAN}

Protein LDAP yang telah diketahui berperan dalam biogenesis minyak pada tanaman Arabidopsis dan buah Alpukat menunjukkan tingkat kedekatan dan konservasi yang besar dengan homolog LDAP yang ada pada tanaman Jarak pagar (Jatropha curcas). Analisis 
penjajaran sekuen asam amino jamak menunjukkan bahwa protein LDAP Jatropha mempunyai idetitas sebesar $67,50 \%$ dengan LDAP3 Arabidopsis; $61,21 \%$ dengan LDAP2 buah Alpukat dan $55,65 \%$ dengan LDAP1 buah Alpukat. Analisis struktur gen menunjukkan bahwa transkrip (mRNA/cDNA) yang menyandikan protein LDAP pada Jatropha memiliki 3 ekson dan 2 intron yang juga dimiliki oleh Arabdiposis. Berbeda dengan LDAP pada Arabidopsis, LDAP Jatropha mempunyai kemiripan indeks hidropfobisitas dengan LDAP buah Alpukat. Asam-asam amino pada area 2040 menunjukkan karakteristik hidropfobisitas yang tinggi yang memberikan implikasi posisi mereka lebih berada pada bagian dalam membrane lemak lapis ganda (bilayer). LDAP pada Jatropha berpotensi menjadi target dalam studi bioteknologi molekuler dengan rekayasa genetika dalam upaya meningkatkan kadar minyak yang bisa dimanfaatkan dalam pengembangan biofuel atau bahan bakar terbarukan

\section{DAFTAR PUSTAKA}

Bateman, A., Coin, L., Durbin, R., Finn, R. D., Hollich, V., Griffiths-Jones, S., Khanna, A., Marshall, M., Moxon, S., \& Sonnhammer, E. L. (2004). The Pfam protein families database. Nucleic Acids Research, 32(suppl_1), D138-D141.

Berchmans, H. J., \& Hirata, S. (2008). Biodiesel production from crude Jatropha curcas L. seed oil with a high content of free fatty acids. Bioresource Technology, 99(6), 1716-1721.

Brinkman, F. S., Wan, I., Hancock, R. E., Rose, A. M., \& Jones, S. J. (2001). PhyloBLAST:

Facilitating phylogenetic analysis of BLAST results. Bioinformatics, 17(4), 385387.

Chapman, K. D., Dyer, J. M., \& Mullen, R. T. (2012). Biogenesis and functions of lipid droplets in plants thematic review series: Lipid droplet synthesis and metabolism: from yeast to man.
Journal of Lipid Research, 53(2), 215-226.

Chenna, R., Sugawara, H., Koike, T., Lopez, R., Gibson, T. J., Higgins, D. G., \& Thompson, J. D. (2003). Multiple sequence alignment with the Clustal series of programs. Nucleic Acids Research, 31(13), 3497-3500.

Cruz, A. L., Carrossini, N., Teixeira, L. K., Ribeiro-Pinto, L. F., Bozza, P. T., \& Viola, J. P. (2019). Cell cycle progression regulates biogenesis and cellular localization of lipid droplets. Molecular and Cellular Biology, 39(9), e00374-18.

Damodharan, L., \& Pattabhi, V. (2004). Hydropathy analysis to correlate structure and function of proteins. Biochemical and Biophysical Research Communications, 323(3), 996-1002.

D'Onofrio, G., Jabbari, K., Musto, H., \& Bernardi, G. (1999). The correlation of protein hydropathy with the base composition of coding sequences. Gene, 238(1), 3-14.

Durrett, T. P., Benning, C., \& Ohlrogge, J. (2008). Plant triacylglycerols as feedstocks for the production of biofuels. The Plant Journal, 54(4), 593-607.

Eboibi, B. E., Eboibi, O., Okputu, J., \& Okpohwo, K. A. (2018). Production and analysis of biodiesel from Jatropha curcas seed. Journal of Applied Sciences and Environmental Management, 22(1), 26-33.

Felber, J.-P., \& Golay, A. (1995). Regulation of nutrient metabolism and energy expenditure. Metabolism, 44, 4-9.

Fuentes, A., García, C., Hennecke, A., \& Masera, O. (2018). Life cycle assessment of Jatropha curcas biodiesel production: A case study in Mexico. Clean Technologies and Environmental Policy, 20(7), 17211733. 
Gasteiger, E., Hoogland, C., Gattiker, A., Wilkins, M. R., Appel, R. D., \& Bairoch, A. (2005). Protein identification and analysis tools on the ExPASy server. In The proteomics protocols handbook (pp. 571-607). Springer.

Ghosh, P., Westhoff, P., \& Debnath, D. (2019). Biofuels, food security, and sustainability. In Biofuels, Bioenergy and Food Security (pp. 211-229). Elsevier.

Gidda, S. K., Park, S., Pyc, M., Yurchenko, O., Cai, Y., Wu, P., Andrews, D. W., Chapman, K. D., Dyer, J. M., \& Mullen, R. T. (2016). Lipid droplet-associated proteins (LDAPs) are required for the dynamic regulation of neutral lipid compartmentation in plant cells. Plant Physiology, 170(4), 20522071.

Gidda, S. K., Watt, S. C., Collins-Silva, J., Kilaru, A., Arondel, V., Yurchenko, O., Horn, P. J., James, C. N., Shintani, D., \& Ohlrogge, J. B. (2013). Lipid droplet-associated proteins (LDAPs) are involved in the compartmentalization of lipophilic compounds in plant cells. Plant Signaling \& Behavior, 8(11), e27141.

Goodman, J. M. (2008). The gregarious lipid droplet. Journal of Biological Chemistry, 283(42), 28005-28009.

Greenway, H., \& Gibbs, J. (2003). Mechanisms of anoxia tolerance in plants. II. Energy requirements for maintenance and energy distribution to essential processes. Functional Plant Biology, 30(10), 999-1036.

Gübitz, G. M., Mittelbach, M., \& Trabi, M. (1999). Exploitation of the tropical oil seed plant Jatropha curcas $\mathrm{L}$. Bioresource Technology, 67(1), 7382.

Hood, E. E. (2016). Plant-based biofuels. F1000Research, 5.

Horn, P. J., James, C. N., Gidda, S. K., Kilaru, A., Dyer, J. M., Mullen, R. T., Ohlrogge, J. B., \& Chapman, K. D.
(2013). Identification of a new class of lipid droplet-associated proteins in plants. Plant Physiology, 162(4), 1926-1936.

Jones, D. T., Taylor, W. R., \& Thornton, J. M. (1992). The rapid generation of mutation data matrices from protein sequences. Bioinformatics, 8(3), 275-282.

Lu, H., Liu, Y., Zhou, H., Yang, Y., Chen, M., \& Liang, B. (2009). Production of biodiesel from Jatropha curcas L. oil. Computers \& Chemical Engineering, 33(5), 1091-1096.

Martin, S., \& Parton, R. G. (2006). Opinion: Lipid droplets: a unified view of a dynamic organelle. Nature Reviews Molecular Cell Biology, 7(5), 373-378.

McGinnis, S., \& Madden, T. L. (2004). BLAST: at the core of a powerful and diverse set of sequence analysis tools. Nucleic Acids Research, 32(2), W20-W25.

Meyer, E., Logan, T. L., \& Juenger, T. E. (2012). Transcriptome analysis and gene expression atlas for Panicum hallii var. Filipes, a diploid model for biofuel research. The Plant Journal, 70(5), 879-890.

Mohanty, S. K., \& Swain, M. R. (2019). Bioethanol Production From Corn and Wheat: Food, Fuel, and Future. In Bioethanol Production from Food Crops (pp. 45-59). Elsevier.

Olzmann, J. A., \& Carvalho, P. (2019). Dynamics and functions of lipid droplets. Nature Reviews Molecular Cell Biology, 20(3), 137-155.

Openshaw, K. (2000). A review of Jatropha curcas: An oil plant of unfulfilled promise. Biomass and Bioenergy, 19(1), 1-15.

Powlson, D. S., Riche, A. B., \& Shield, I. (2005). Biofuels and other approaches for decreasing fossil fuel emissions from agriculture. Annals of Applied Biology, 146(2), 193-201.

Pramanik, K. (2003). Properties and use of Jatropha curcas oil and diesel fuel 
blends in compression ignition engine. Renewable Energy, 28(2), 239-248.

Saudale, F., \& Boelan, E. (2018). Aktivitas Antibakteri Ekstrak Polar dan Non Polar Biji Kelor (Moringa oleifera) Asal Pulau TImor NTT. Jurnal Sains Dan Teknologi, 7(1), 67-76.

Sievers, F., \& Higgins, D. G. (2018). Clustal Omega for making accurate alignments of many protein sequences. Protein Science, 27(1), 135-145.

Sievers, F., Wilm, A., Dineen, D., Gibson, T. J., Karplus, K., Li, W., Lopez, R., McWilliam, H., Remmert, M., Soding, J., Thompson, J. D., \& Higgins, D. G. (2011). Fast, scalable generation of high-quality protein multiple sequence alignments using Clustal Omega. Molecular Systems Biology, 7, 539.
Silitonga, A. S., Atabani, A. E., Mahlia, T. M. I., Masjuki, H. H., Badruddin, I. A., \& Mekhilef, S. (2011). A review on prospect of Jatropha curcas for biodiesel in Indonesia. Renewable and Sustainable Energy Reviews, 15(8), 3733-3756.

Tiwari, A. K., Kumar, A., \& Raheman, H. (2007). Biodiesel production from jatropha oil (Jatropha curcas) with high free fatty acids: An optimized process. Biomass and Bioenergy, 31(8), 569-575.

Ye, J., McGinnis, S., \& Madden, T. L. (2006). BLAST: Improvements for better sequence analysis. Nucleic Acids Research, 34(suppl_2), W6W9. 